\title{
Immunoreactive gastrin components in human serum
}

\author{
JENS F. REHFELD', FLEMMING STADIL, AND JøRGEN VIKELSøE \\ From the Department of Clinical Chemistry, Bispebjerg Hospital, and the Department of Gastroenterology \\ C, Rigshospitalet, Copenhagen, Denmark
}

SUMMARY The apparent molecular size and charge of immunoreactive gastrin components were studied in sera from patients with pernicious anaemia or gastrinomas (the Zollinger-Ellison syndrome) by Sephadex gel filtration and aminoethylcellulose chromatography. The following serum components were distinguished: (1) a monophasic component I similar in size to proinsulin which was converted into 'little' gastrin I by trypsin digestion; (2) a biphasic component II, corresponding to 'big' gastrins I and II (Gregory and Tracy); (3) a biphasic component III corresponding to 'little' gastrins I and II (Gregory and Tracy); and (4) a biphasic component IV, corresponding to 'minigastrins' I and II (Gregory and Tracy). 'Big, big' gastrin, a plasma component found in the void volume of the Sephadex G-50 column by Yalow and Berson (1972) was undetectable in the sera investigated. A component in gastrinoma and antral mucosa extracts corresponding in size to 'big big' gastrin was detectable by the assay; the 'big big' gastrin fraction from gastrinoma tissue was heterogenous, with components of apparent MW 30000-100 000. It is concluded that serum gastrin circulates in the form of at least four components, of which the three smaller ones are in pairs.

Like other protein and peptide hormones (Franchimont, Gaspard, Reuter, and Heynen, 1972), immunoreactive gastrin circulates as components of different size and charge (Yalow and Berson, 1970, 1971; Rehfeld, 1972). It has been shown (Yalow and Berson, 1971; Rehfeld, 1972) that the larger components are not polymers of the heptadecapeptide gastrins isolated and purified by Gregory and Tracy (1964).

Employing gel filtration with high resolution and a sensitive radioimmunoassay we have recently been able to demonstrate that gastrin in peripheral blood from subjects with gastrin-producing tumours (Zollinger-Ellison syndrome) consists of four components of different molecular size (Rehfeld and Stadil, 1973a). The gel filtration studies also indicated that component II ('big' gastrin) and component III ('little' gastrin) might circulate in pairs. The two peaks in component III were eluted

${ }^{1}$ Correspondence to: J. F. Rehfeld, Department of Clinical Chemistry, Bispebjerg Hospital, Bispebjerg Bakke 23, DK-2400 Copenhagen NV, Denmark

Received for publication 9 October 1973. in the same positions as the sulphated and nonsulphated heptadecapeptides respectively, and the biphasic elution pattern of component II observed in some cases seemed in accordance with the recent study of Gregory and Tracy (1972), who isolated a pair of 'big' gastrins from gastrin tumour tissue.

The present study is concerned with further characterization of the immunoreactive components of gastrin in serum.

\section{Materials}

Peripheral sera were obtained from patients with hypergastrinaemia (pernicious anaemia or gastrinoma (the Zollinger-Ellison syndrome)). The concentration of immunoreactive gastrin in serum varied from 140 to 131000 pmoles/1. A specimen of antral vein blood was obtained from a pig.

Purified human 'big' gastrins I and II, 'mini' gastrins I and II (non-sulphated and sulphated forms respectively), and fractions from ZollingerEllison tumour tissue corresponding to 'big big' gastrin (Yalow and Berson, 1972) and component I 
(Rehfeld, 1972) were kindly given by Professor R. A. Gregory and Dr Hilda Tracy, Liverpool, England.

The other materials were obtained from the following sources: Sephadex G-10, G-50 superfine, and Sephadex G-100 superfine from Pharmacia Inc, Uppsala, Sweden; aminoethylcellulose (Whatman AE 41), W \& R Balston Ltd, Maidstone, England; synthetic human gastrin I from Imperial Chemical Industries, Cheshire, England; highly purified porcine gastrin II (lot no. 66/138) from Division of Biological Standards, National Institute of Medical Research, Mill Hill, London, England. ${ }^{125}$ I-labelled human immunoglobulin $M$ (IgM) (specific radioactivity 4 ? $\mu \mathrm{Ci} / \mathrm{mg}$ ) was kindly given by $\mathrm{K}$. Birger Jensen, DMSc. ${ }^{125} \mathrm{I}$-labelled human albumin (specific radioactivity $2.5 \mu \mathrm{Ci} / \mathrm{mg}$ ) and ${ }^{22} \mathrm{NaCl}$ (specific radioactivity $100 \mathrm{mCi} / \mathrm{mg}$ ) were obtained from the Radiochemical Centre, Amersham, England. Human monocomponent insulin and monocomponent porcine proinsulin were gifts from $\mathrm{Dr}$ J. Schlichtkrull and L. Heding, $\mathrm{PhD}$, NOVO, Copenhagen. Trypsin 'essentially free of chymotrypsin' (lot no. 101215) came from Calbiochem, San Diego, Calif, USA, and Trasylol aprotinin, from Bayer, Leverkusen, W. Germany.

Radioactivity was measured in a well-type scintillation counter ND-(Selektronik, Copenhagen). Samples were concentrated in a Büchi Rotavapor $R$, type KRv 64/65, Flawil, Switzerland. The gradient mixer was from Pharmacia Inc, Uppsala, Sweden.

\section{Methods}

SAMPLING AND TREATMENT OF SERA

Peripheral blood from three subjects immediately after drawing was distributed into seven tubes prepared in the following manner: (1) a sterile test tube placed at $4^{\circ} \mathrm{C}$ to which $1.0 \mathrm{ml}$ aprotinin per $10 \mathrm{ml}$ blood was added; (2) a non-sterile test tube placed at $4^{\circ} \mathrm{C}$ with the addition of aprotinin (as above); (3) a non-sterile test tube placed at $20^{\circ} \mathrm{C}$ with the addition of aprotinin (as above); (4) a non-sterile test tube placed at $4^{\circ} \mathrm{C}$ without aprotinin; (5) a non-sterile test tube placed at $20^{\circ} \mathrm{C}$ without aprotinin; (6) same treatment as (5), but with separation of serum delayed for 24 hours; (7) a non-sterile test tube without the addition of aprotinin boiled for three minutes.

\section{FRACTIONATION PROCEDURES}

Serum samples or solutions of gastrins in a volume of 1.0 to $1.5 \mathrm{ml}$ were applied to Sephadex G-50 superfine columns, $10 \times 2000 \mathrm{~mm}$, with a constant flow rate of $5.4 \mathrm{ml} / \mathrm{hr}$ at $20^{\circ} \mathrm{C}$. The columns were eluted with $0.1 \mathrm{M}$ sodium phosphate buffer, pH 7.4, containing $0.6 \mathrm{mM}$ ethylmercuric thiosalicylate. These columns were calibrated with ${ }^{125} \mathrm{I}$-albumin, ${ }^{22} \mathrm{NaCl}$, monocomponent human insulin, porcine proinsulin, synthetic human gastrin I, and highly purified porcine gastrin II. Before each application of serum ${ }^{125} \mathrm{I}$-albumin and ${ }^{22} \mathrm{Na}$ were added to the sample for internal standardization. Fractions of $1.5 \mathrm{ml}$ were collected.

Serum samples of 12 to $15 \mathrm{ml}$ were applied to Sephadex G-50 superfine columns, $75 \times 1000$ $\mathrm{mm}$, with a constant flow rate of $75 \mathrm{ml} / \mathrm{hr}$ at $20^{\circ} \mathrm{C}$. The columns were eluted with $0.1 \mathrm{M}$ sodium phosphate, pH 7.4 , containing $0.6 \mathrm{mM}$ ethylmercuric thiosalicylate. The columns were calibrated as above. Fractions of $12 \mathrm{ml}$ were collected.

Gastrin samples of $2.0 \mathrm{ml}$ were applied to Sephadex G-100 superfine column, $20 \times 1000 \mathrm{~mm}$, with a constant flow rate of $18 \mathrm{ml} / \mathrm{hr}$ at $20^{\circ} \mathrm{C}$. The column was eluted with $0.1 \mathrm{M}$ sodium phosphate, pH 7.4, containing $0.6 \mathrm{mM}$ ethylmercuric thiosalicylate. The column was calibrated with ${ }^{125} \mathrm{I}$ IgM, ${ }^{125} \mathrm{I}$-albumin, and ${ }^{22} \mathrm{NaCl}$. Fractions of $2.3 \mathrm{ml}$ were collected.

Serum gastrin components were isolated by gel filtration on Sephadex G-50 superfine column, $75 \times 1000 \mathrm{~mm}$. Pooled fractions of each component were concentrated on the Rotavapor. The concentrates were refiltrated on Sephadex G-50 superfine columns $(10 \times 2000 \mathrm{~mm})$ and then diluted or desalted on Sephadex G-10 columns eluted with $0.05 \mathrm{M}$ ammonium hydrogen carbonate. Samples of the isolated components I and II were incubated with trypsin as previously described (Rehfeld, 1972) and subjected to gel filtration as described above.

The void volume from the G-10 columns or the diluted solutions was mixed with monoiodinated ${ }^{125}$ I-synthetic human gastrin I (Stadil and Rehfeld, 1972) and applied to an AE 41 cellulose column, $10 \times 150 \mathrm{~mm}$. The sample was eluted with ammonium hydrogen carbonate at a flow rate of $30 \mathrm{ml} / \mathrm{hr}$ at $20^{\circ} \mathrm{C}$ by a linear gradient from 0.05 to $0.4 \mathrm{M}$ ammonium hydrogen carbonate. The reservoirs in the gradient mixer were filled with $250 \mathrm{ml}$ of each buffer. Fractions of $1.5 \mathrm{ml}$ were collected from the column.

\section{RADIOIMMUNOANALYSIS}

Immunoreactive gastrin in sera and column effluents were determined radioimmunochemically using antisera and ${ }^{125} \mathrm{I}$-synthetic human gastrin $\mathrm{I}$ as characterized in detail elsewhere (Stadil and Rehfeld, 1972; Rehfeld, Stadil, and Rubin, 1972). The reactivity against cholecystokinin of the antisera used in the present study to investigate the relationship to cholecystokinin is expressed by the ratio 
between inhibition doses 50 for synthetic human gastrin I (ICI) and 99\% pure porcine cholecystokinin (Mutt and Jorpes). Inhibition dose $\mathbf{5 0}$ is the molar concentration of an antigen able to inhibit the antibody binding of the labelled antigen to $50 \%$ of the initial value. For antiserum no. 2604-8 the ratio was 0.002 , for antiserum no. 2716-4 the ratio was 0.046, and for antiserum no. 2720-3 the ratio was 0.20 . The separation method employed in the present study was an anion exchange technique (Rehfeld and Stadil, 1973b). Immunoreactive insulin was determined with a reliable assay characterized in detail elsewhere (Rehfeld and Stadil, 1973c).

\section{Results}

\section{GEL FILTRATION STUDIES OF SERUM \\ GASTRIN COMPONENTS}

\section{Elution diagram on Sephadex G-50 superfine columns ( fig l)}

The gastrin immunoreactivity in human serum was distributed in four components of which the two smaller ones appeared biphasic. Component I was eluted in the same position as proinsulin. Component II was eluted in a position between proinsulin and mono-component insulin. Component III was eluted in two peaks, the first one in a position similar to the sulphated heptadecapeptide, porcine gastrin II, the second in a position similar to the nonsulphated heptadecapeptide, synthetic human gastrin I. Component IV was eluted in one broad or two distinct peaks immediately before the salt peak.

Gastrin immunoreactivity in porcine antral vein serum was distributed in components similar to those found in human serum. A greater fraction of the total immunoreactivity was found in the smaller components.

Significance of the manner in which blood or serum is treated after drawing

Cooling, boiling for three minutes, the addition of
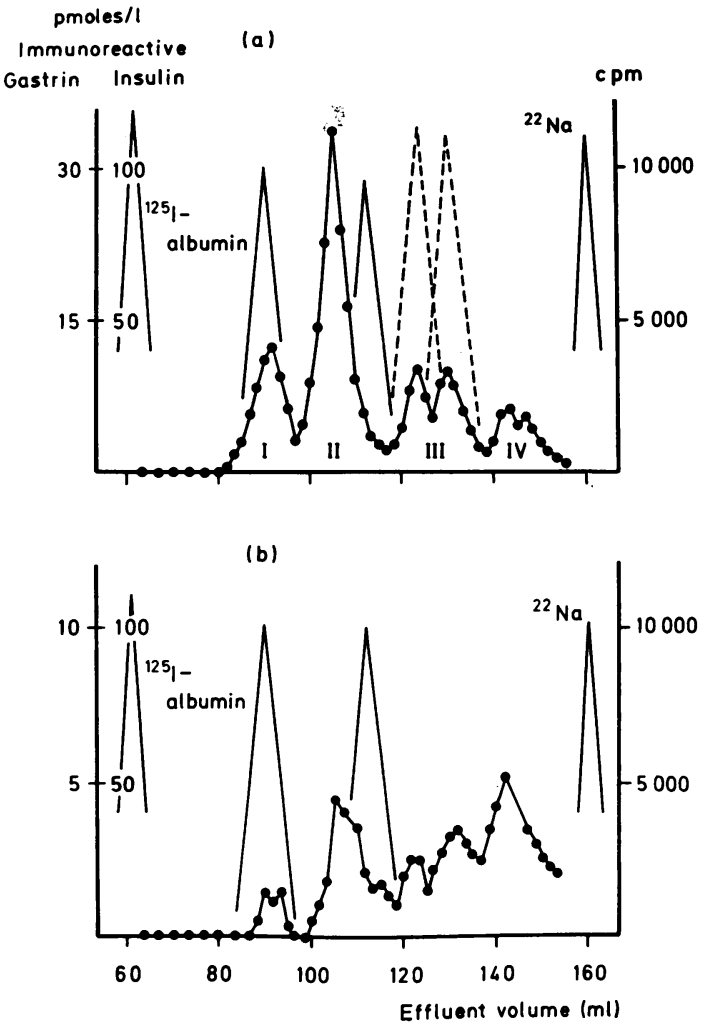

Fig 1 Distribution of gastrin immunoreactivity in serum (-) by gel filtration on Sephadex G-50 superfine columns $(10 \times 2000 \mathrm{~mm})$. The columns were calibrated with ${ }^{125}$ I-albumin, proinsulin, and monocomponent insulin (- $\longrightarrow$, the heptadecapeptide gastrins I and II (- . . - -), and ${ }^{22} \mathrm{NaCl}$. (a) Human serum. (b) Porcine serum from an antral vein. Porcine serum was gel filtrated for comparison since the sulphated heptadecapeptide, gastrin II, used for calibration was of porcine origin.

proteolytic inhibitor, and the use of sterile tubes was without effect on the number of components in the elution pattern and the fraction of the gastrin

\begin{tabular}{|c|c|c|c|c|c|c|}
\hline & \multirow[t]{2}{*}{ Component I } & \multirow[t]{2}{*}{ Component II } & \multicolumn{2}{|c|}{ Component III } & \multicolumn{2}{|c|}{ Component IV } \\
\hline & & & Peak 1 & Peak 2 & Peak 1 & Peak 2 \\
\hline $\begin{array}{l}\text { + Aprotinin } 4^{\circ} \mathrm{C}, \mathrm{s}^{1} \\
\text { + Aprotinin } 4^{\circ} \mathrm{C}, \mathrm{n}-\mathrm{s}^{1} \\
\text { + Aprotinin } 20^{\circ} \mathrm{C}, \mathrm{n}-\mathrm{s} \\
\text { - Aprotinin } 4^{\circ} \mathrm{C}, \mathrm{n}-\mathrm{s} \\
\text { - Aprotinin } 20^{\circ} \mathrm{C}, \mathrm{n}-\mathrm{s} \\
\text { - Aprotinin } 20^{\circ} \mathrm{C}, \mathrm{n}-\mathrm{s} \text { (delayed separation) } \\
\text { - Aprotinin } 100^{\circ} \mathrm{C} \text {, }\end{array}$ & $\begin{array}{l}0.06 \\
0.07 \\
0.05 \\
0.06 \\
0.07 \\
0.05 \\
0.06\end{array}$ & $\begin{array}{l}0.69 \\
0.67 \\
0.70 \\
0.56 \\
0.69 \\
0 \cdot 66 \\
0.67\end{array}$ & $\begin{array}{l}0 \cdot 13 \\
0 \cdot 14 \\
0 \cdot 12 \\
0 \cdot 15 \\
0 \cdot 12 \\
0 \cdot 17 \\
0 \cdot 15\end{array}$ & $\begin{array}{l}0.08 \\
0.08 \\
0.08 \\
0 \cdot 11 \\
0.07 \\
0.07 \\
0.07\end{array}$ & $\begin{array}{l}0.02 \\
0.02 \\
0.03 \\
0.07 \\
0.02 \\
0.03 \\
0.03\end{array}$ & $\begin{array}{l}0.02 \\
0.02 \\
0.02 \\
0.05 \\
0.03 \\
0.02 \\
0.02\end{array}$ \\
\hline
\end{tabular}

Table Fraction size of immunoreactive gastrin components as defined by gel filtration after various treatments of blood and serum (mean, $n=3$ ) 


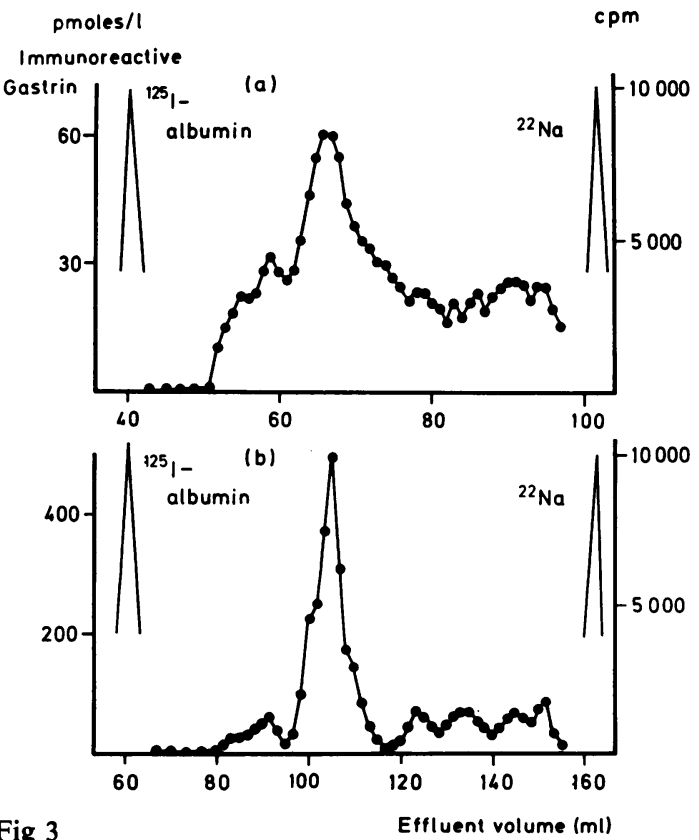

Fig 2 Distribution of gastrin immunoreactivity (O_ ). (a) Untreated serum. (b) Serum boiled for three minutes. Both sera were from the same sample.

Fig 3 Distribution of gastrin immunoreactivity (O) in serum from one subject by gel filtration (a) On Sephadex G-50 fine column, $10 \times 1100 \mathrm{~mm}$, employing $0.02 \mathrm{M}$ veronal buffer, $\mathrm{pH} 8.4$. (b) On Sephadex G-50 superfine column, $10 \times 2000 \mathrm{~mm}$, was eluted with $0 \cdot 1 \mathrm{M}$ sodium phosphate, $\mathrm{pH} 7 \cdot 4$.

Fig 4 Distribution of gastrin immunoreactivity (-) by gel filtration on Sephadex G-50 superfine columns, $10 \times 2000 \mathrm{~mm}$, eluted with $0 \cdot 1 \mathrm{M}$ sodium phosphate, $\mathrm{pH} 7 \cdot 4$. The gastrin immunoreactivity was measured with (a) antiserum 2604, (b) antiserum 2716, (c) antiserum 2720.

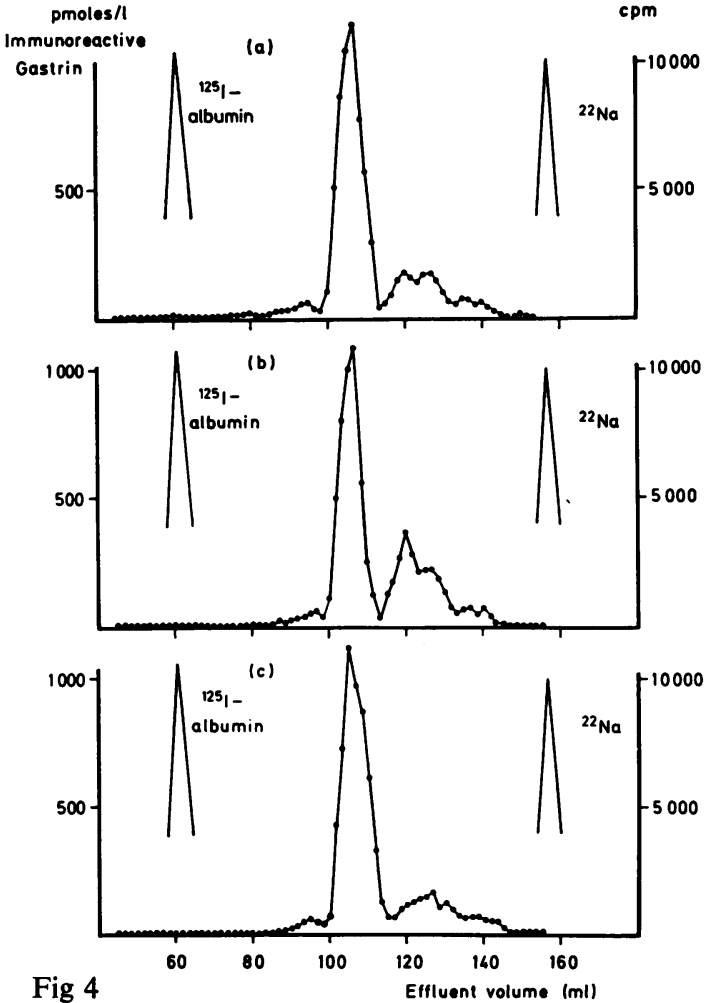

Fig 3 

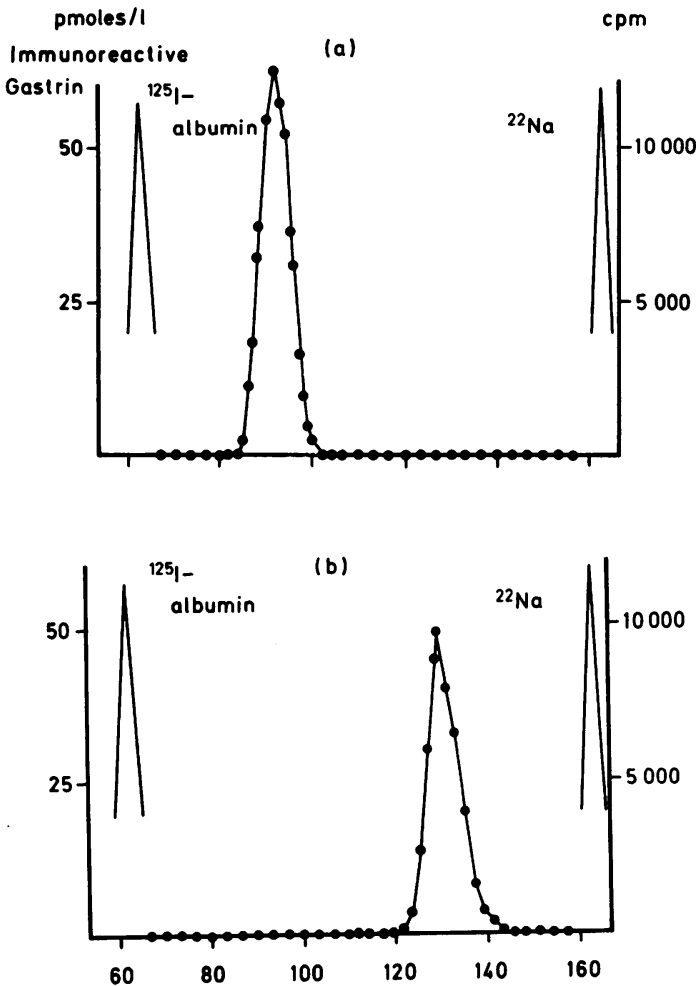

Fig 5

pmoles $/ 1$
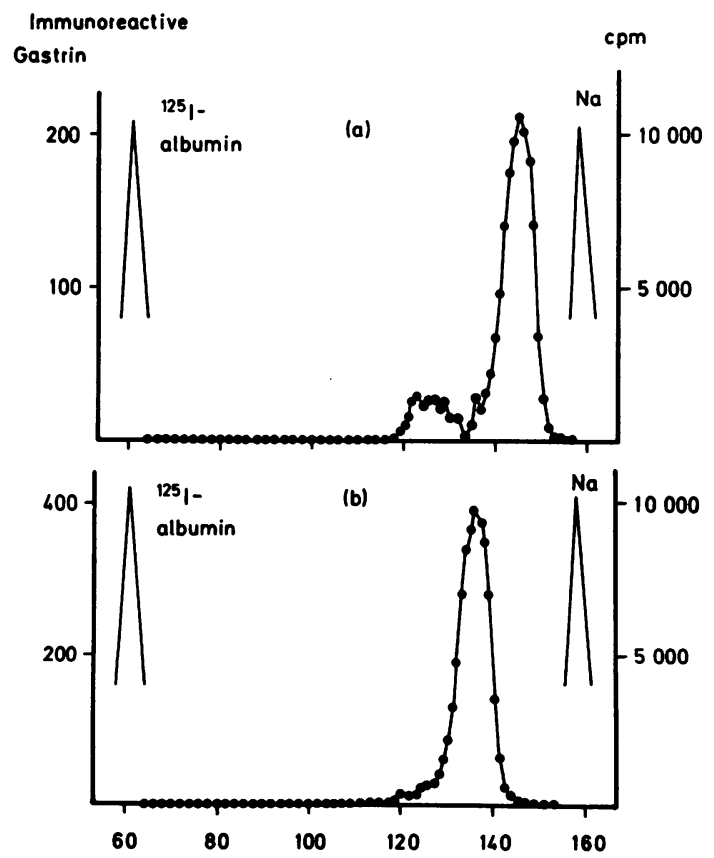

Fig 7
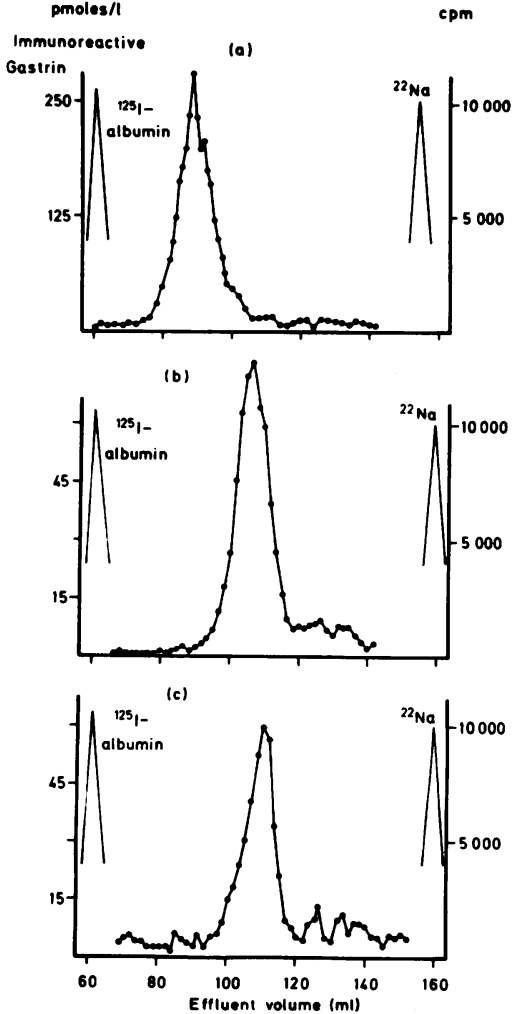

Fig 6

Fig 5 Elution of the gastrin immunoreactivity of component I from serum (- - ) by gel filtration on Sephadex G-50 superfine columns, $10 \times 2000 \mathrm{~mm}$. (a) Component I isolated by refiltration. (b) The isolated component I after incubation with trypsin.

Fig 6 Distribution of gastrin immunoreactivity in components isolated from gastrinoma tissue by gel filtration on Sephadex G-50 superfine columns $(10 \times 2000 \mathrm{~mm})$. (a) Component I. (b) The sulphated form of component II. (c) The non-sulphated form of component II.

Fig 7 Distribution of gastrin immunoreactivity in component $I V$ isolated from gastrinoma tissue (O-O) by gel filtration on Sephadex G-50 superfine columns, $10 \times 2000 \mathrm{~mm}$. (a) Component IV, non-sulphated form. (b) Component IV, sulphated form. 


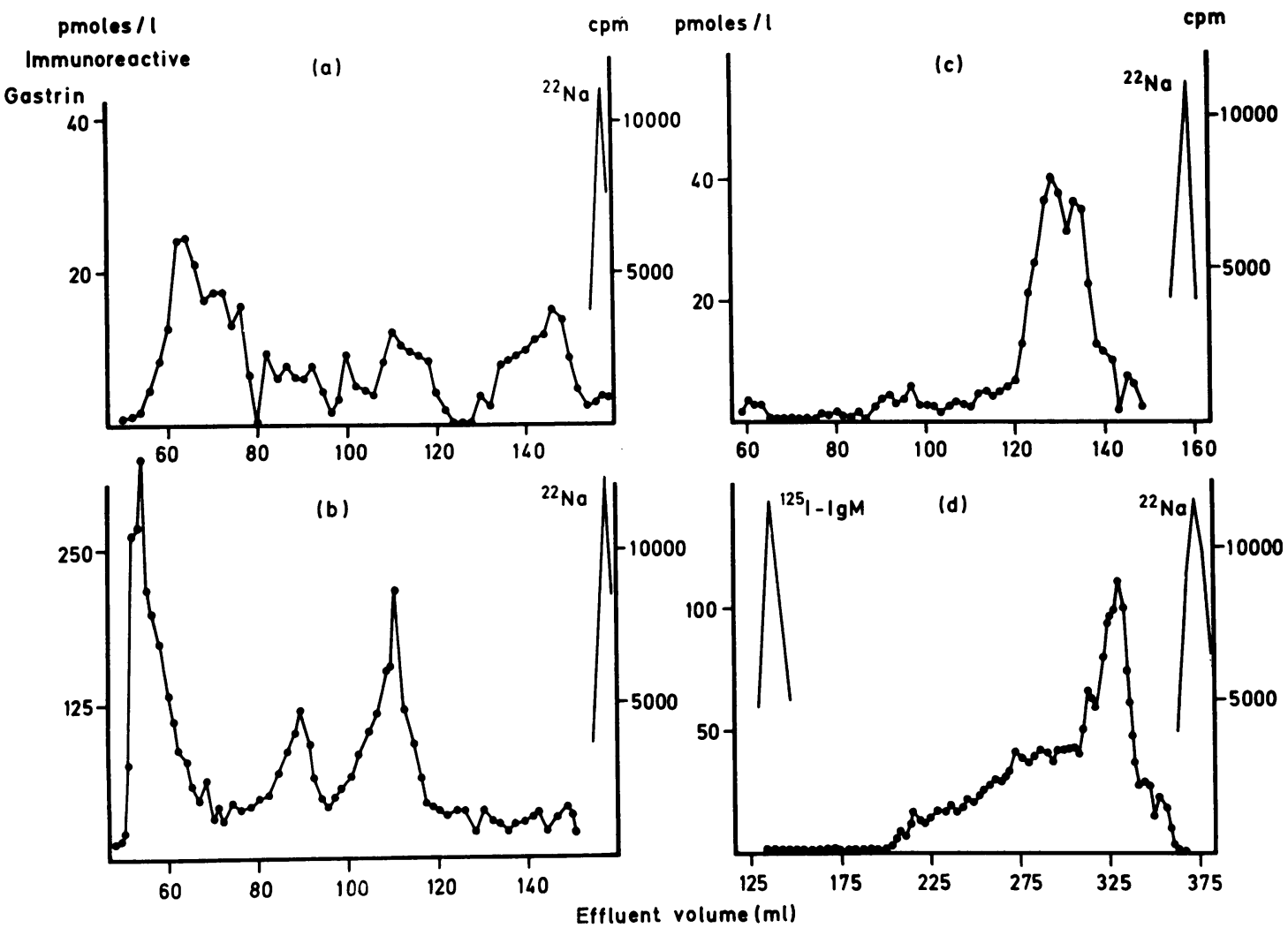

Fig 8 Distribution of gastrin immunoreactivity in 'big big' gastrin from gastrinoma tissue (-——) by gel filtration on Sephadex G-50 superfine columns, $10 \times 2000 \mathrm{~mm}$. (a) 'Big big' gastrin without pretreatment. (b) 'Big big' gastrin preincubated with $8 \mathrm{M}$ urea and gel filtrated in a urea gradient. (c) 'Big big' gastrin preincubated with trypsin. (d) 'Big big' gastrin gel filtrated on a Sephadex G-100 superfine column, $20 \times 1000 \mathrm{~mm}$.

immunoreactivity contained in each component (see table and fig 2).

Significance of Sephadex quality and buffers (fig 3) Resolution of gastrin components was poorer on Sephadex G-50 fine columns than on Sephadex G-50 superfine columns. The use of $0.02 \mathrm{M}$ veronal buffer, $\mathrm{pH} 8 \cdot 4$, or sodium phosphate buffer, $\mathrm{pH} 7 \cdot 4$, both afforded recoveries in a range from 70 to $125 \%$, whereas $0.05 \mathrm{M}$ ammonium hydrogen carbonate resulted in lower recoveries (range 20 to $60 \%$ ). All components were found irrespectively of the buffer employed.

Immunoreactivity of gastrin components The elution patterns of the gastrin immunoreactivity were similar employing three antisera with different specificity towards cholecystokinin (fig 4).
Isolation and gel re-filtration of component I (fig 5) Component I was isolated after two gel filtrations. The isolated component was eluted in the same position by gel re-filtration. By trypsin treatment component I was converted to a component eluted in a position similar to the non-sulphated heptadecapeptide, gastrin I.

\section{GEL FILTRATION STUDIES OF GASTRIN COMPONENTS FROM GASTRINOMA TISSUE}

\section{Elution diagrams of components I, II, and IV}

(figs 6 and 7)

'Tissue-component I' was a preparation purified by Dr Hilda Tracy by chromatography on aminoethylcellulose, obtained from a gastrinoma extract fractionated on Sephadex G-50 superfine. On Sephadex G-50 superfine columns it was eluted in a 

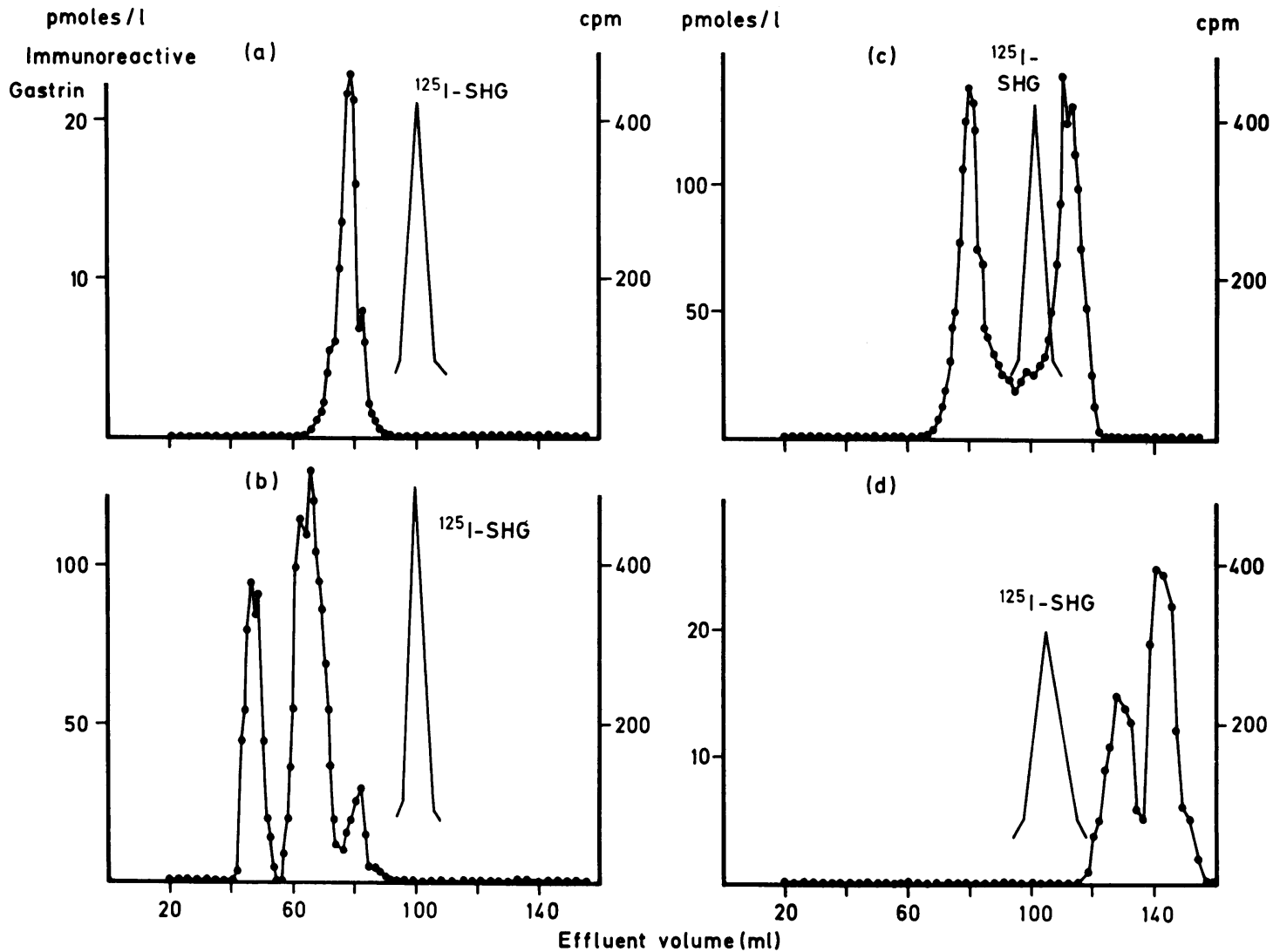

Fig 9 Distribution of gastrin immunoreactivity of the components isolated from serum (-C) by ion exchange chromatography on AE 41 cellulose columns, $10 \times 150 \mathrm{~mm}$. (a) Component I. (b) Component II. (c) Component III. (d) Component IV. ${ }^{125}$ I-synthetic human gastrin I (SHG) was used as marker.

single peak in a position identical with that of the serum component $\mathrm{I}$. The purified preparations of 'big' gastrins I and II from gastrinoma tissue contained detectable amounts of other immunoreactive material; they emerged in overlapping positions which corresponded respectively to the later (BGI) and earlier (BGII) portions of the biphasic peak of component II from serum. Minigastrins I and II, the non-sulphated and sulphated members of a pair of tridecapeptide gastrins isolated by Gregory and Tracy from gastrinoma tissue in a study as yet unpublished, emerged in a position corresponding to the first and second peaks respectively of component IV from serum.

Elution diagram of a tissue gastrin component found in the void volume of a preparative Sephadex G-50 column ( fig 8)

This preparation was obtained from the filtration on a large Sephadex G-50 superfine column of a partially purified preparation from gastrinoma tissue; it emerged in the void volume and so corresponded in position to that of the 'big big' gastrin component described in plasma by Yalow and Berson. On gel filtration in the present study the material was heterogenous; a prominent peak of immunoreactivity appeared in the void volume, followed by a number of poorly defined smaller components. After incubation with $8 \mathrm{M}$ urea followed by gel filtration in a urea gradient as previously described (Rehfeld, 1972), the elution pattern became clearer; approximately one-third of the immunoreactive gastrin was eluted in the void volume, followed by well defined peaks corresponding in position to serum components I and II. After trypsin digestion most of the gastrin immunoreactivity from these three regions was converted into heptadecapeptide-like ('little' gastrin) material 

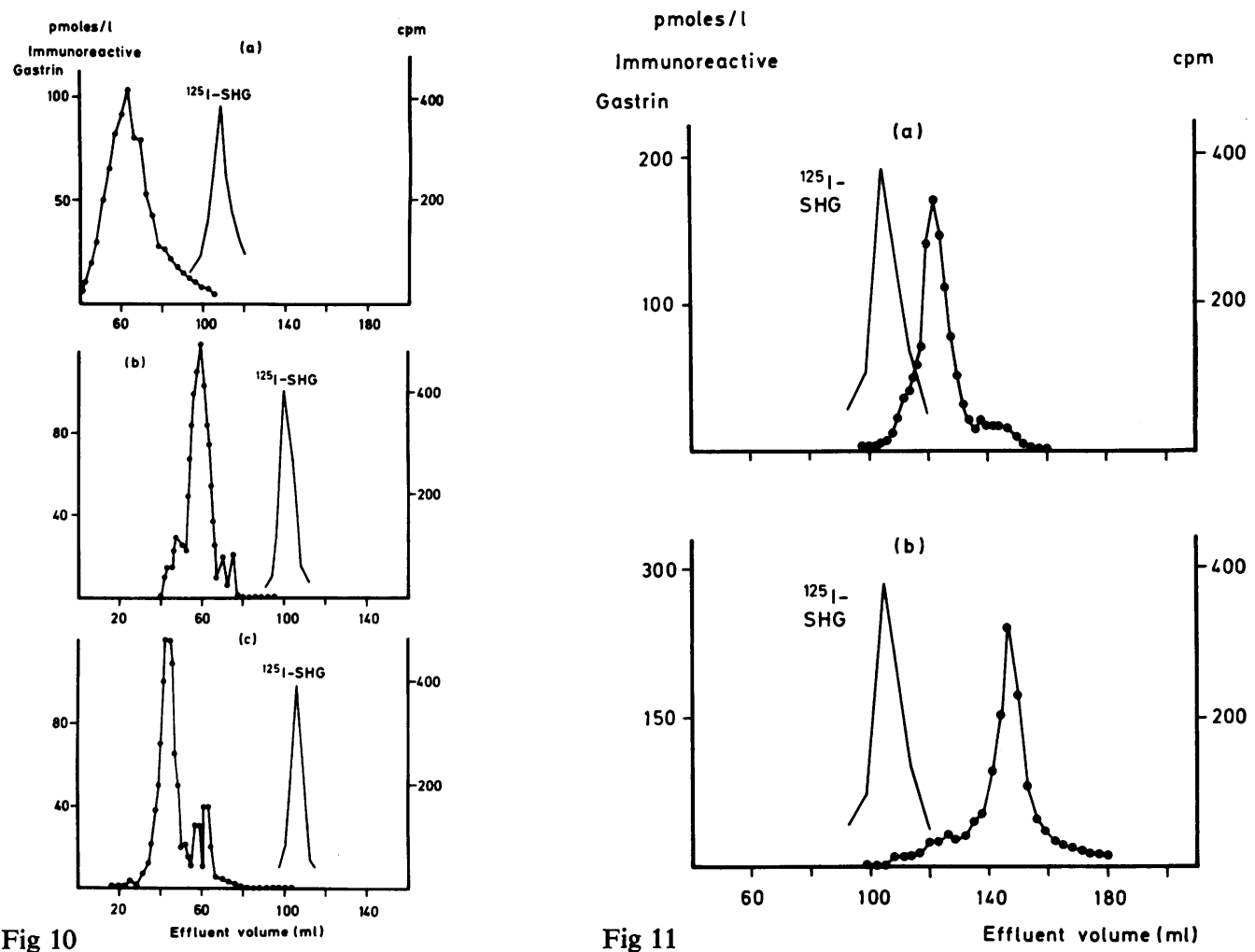

Fig 10

Fig 11

Fig 10 Distribution of gastrin immunoreactivity in components isolated from gastrinoma tissue ( exchange chromatography on AE 41 cellulose columns, $10 \times 150 \mathrm{~mm}$. (a) Component I. (b) Component II, sulphated form. (c) Component II, non-sulphated form. ${ }^{125}$ I-synthetic human gastrin I (SHG) was used as marker.

Fig 11 Distribution of gastrin immunoreactivity in component IV isolated from gastrinoma tissue (- - ) by ion exchange chromatography on AE 41 cellulose columns, $10 \times 150 \mathrm{~mm}$. (a) Component IV, non-sulphated form.

(b) Component IV, sulphated form. ${ }^{125}$ I-synthetic human gastrin I (SHG) was used as marker.

On gel filtration on Sephadex G-100 superfine of the original preparation the immunoreactivity was eluted over a broad range; a major peak which emerged immediately in front of the 'salt' region $\left({ }^{22} \mathrm{Na}\right)$ corresponded to components $\mathrm{I}$ and II as defined by Sephadex G-50 filtration.

\section{ION EXCHANGE CHROMATOGRAPHIC STUDIES OF GASTRIN COMPONENTS}

\section{Elution diagram of isolated gastrin components} from serum ( $f$ ig 9)

Component I was eluted in one peak in front of the labelled heptadecapeptide. Component II emerged in two major peaks significantly earlier than ${ }^{125} \mathrm{I}-$ labelled synthetic heptadecapeptide gastrin. A small peak was eluted just behind the last of the two major peaks in a position similar to that of component I. Component III emerged in two peaks immediately before and after the iodinated synthetic human gastrin I respectively. Component IV was eluted in two peaks, emerging significantly later than the iodinated heptadecapeptide-marker.

\section{Elution diagram of isolated gastrin components} from gastrinoma tissue (figs 10 and 11)

Component $I$ from tumour tissue emerged in one fairly broad peak significantly earlier than the labelled heptadecapeptide-marker, and also earlier than component I from serum. The non-sulphated variety of component II ('big' gastrin I) was eluted in a position as the first major peak of the serum 
component, and the sulphated variety emerged in a position similar to the last major peak. The nonsulphated tridecapeptide from gastrinoma tissue ('mini' gastrin I) emerged as the first and the sulphated-tridecapeptide from gastrinoma tissue ('mini' gastrin II) was eluted as the last of the two peaks found in component IV from serum.

\section{Discussion}

The present study indicates that immunoreactive gastrin in serum is heterogenous and circulates as one large component (I) and three smaller paired components (II-IV) with different charges. Compared with the tissue component isolated by Gregory and Tracy, component I from serum emerged later from the aminoethyl ion exchange column. This may be due to a slight difference in charge between serum and tissue component, or to the use of tumour material from Zollinger-Ellison syndromes. Since the smaller gastrin components in serum displayed a behaviour similar to the tissue components by gel filtration, ion exchange chromatography, and polyacrylamide gel electrophoresis (preliminary studies), it is suggested that each of these pairs consists of a sulphated and a non-sulphated form, the sulphate group being attached to the tyrosine residue as known for heptadecapeptide gastrin.

While the present and earlier studies from our laboratory (Rehfeld, 1972; Rehfeld and Stadil, 1973a) confirm the observation of Yalow and Berson $(1970,1971)$ that the major fraction of immunoreactive gastrin in serum or plasma generally is present as component II (or 'big' gastrin), and a minor fraction circulates as heptadecapeptide gastrins (component III or 'little' gastrin), our results do not agree with the previous results of Yalow and Berson concerning the remaining components. Yalow and Berson did not describe components I and IV. This discrepancy is probably in part due to differences in the efficiency of the fractionation procedures employed, since in initial studies we could neither separate component I from component II nor component IV from component III using Sephadex G-50 fine columns with a dimension of $10 \times 500 \mathrm{~mm}$. Columns of the double length afforded a resolution into three components (Rehfeld, 1972); but not until still longer columns and Sephadex G-50 superfine were used, could we clearly separate the gastrin immunoreactivity into four components of different molecular size (fig 2). Moreover, in most gel filtration, the $2 \mathrm{~m}$ long columns permitted a resolution of components III, IV, and in a few instances also component II, into two peaks, the apparent sulphated variety emerging first from the column. We attribute this phenomenon to a weak cation exchange effect of the columns.

In a very recent study Yalow and Wu (1973) have examined the elution patterns of some plasmas to evaluate whether they could detect a component comparable to component I described by us. In plasma from pernicious anaemia and ZollingerEllison patients they found a few per cent gastrin immunoreactivity in fractions corresponding to component I. They found significant amounts of an immunoreactive gastrin component in extract from gastrinoma tissue, provided by Gregory and Tracy with elution volumes similar to component I, and they conclude that plasma probably contains this hormonal form as well. That component I circulates in significant amounts, and in a higher fraction in patients with pernicious anaemia than in ZollingerEllison patients concordant with our previous reports (Rehfeld, 1972; Rehfeld and Stadil, 1973a), has now been confirmed from another laboratory (Vinik, 1973, personal communication).

A year ago Yalow and Berson (1972) reported that 1 to $2 \%$ of the total gastrin immunoreactivity was eluted in the void volume of Sephadex G-50 columns by filtration of plasma from patients with the Zollinger-Ellison syndrome. They named this immunoreactivity 'big big' gastrin. Recently Yalow and $\mathrm{Wu}(1973)$ found that 'big big' gastrin is the major fraction of total gastrin immunoreactivity in plasma from normal subjects in the fasting state. The implications of this finding are not clear. We have not investigated plasma samples from normal fasting subjects, and further studies are needed to confirm that 'big big' gastrin is the predominating component in normal sera as measured with our antisera. A difference in specificity of the antisera of Yalow and his colleagues and ours is unlikely, since our antibodies are able to bind a gastrin fraction in the void volume of a Sephadex G-50 gel filtration of gastrinoma tissue provided by Gregory and Tracy, as well as a similar preparation from antral tissue (unpublished observation). By gel filtration on both Sephadex G-50 and G-100 superfine columns the void volume fraction from gastrinoma tissue was shown to be heterogenous, indicating that it contained a number of immunoreactive components with a molecular mass between 30000 and 100000 daltons.

The almost identical results of different treatment of blood and/or serum samples immediately after drawing as presented here, combined with earlier observations (Rehfeld, 1972) on the gastrin component pattern by gel filtration using human plasma as mobile phase at $37^{\circ} \mathrm{C}$, makes it unlikely that the number and the characteristics of the gastrin components are significantly affected by degradation or 
change of conformation in vitro. Since the component pattern and gastrin concentrations in portal and peripheral serum are similar (Dencker, Håkanson, Liedberg, Norryd, Oscarson, Rehfeld, and Stadil, 1973), the liver is probably without significant effect on the gastrin components.

Many questions are raised by demonstration of the gastrin heterogeneity: the total chemical structure and the biological activity of all components, the biosynthesis of gastrin, and the secretory patterns of the individual components to a number of relevant stimuli. With these problems solved the exploration of the role of gastrin in disease can begin-again.

We are indebted to Professor R. A. Gregory and Dr Hilda Tracy for providing us with gastrin components from tissue, and for stimulating critical discussion of the results obtained in the present study.

The skilful technical assistance of Ulla Søegaard and Ninna Haack is gratefully acknowledged. The study was supported by grants from the Danish Medical Research Council (j.nr. 512-1961, 512-1665, 512-1666), Fonden for Storkøbenhavn, Færøerne og Grønland, Landsforeningen til Kræftens Bekæmpelse, and King Christian d. X's Fond.

\section{References}

Dencker, F. H., Håkanson, R., Liedberg, G., Norryd, D., Oscarson,
J., Rehfeld, J. F., and Stadil, F. (1973). Immunoreactive gastrin in portal and peripheral venous blood during and after feeding in man. Gut, 14, 856-860.

Franchimont, P.. Gaspard, U., Reuter, A., and Heynen, G. (1972). Polymorphism of protein and polypeptide hormones. Clin. Endocr., 1, 315-336.

Gregory, R. A., and Tracy, H. J. (1964). The constitution and properties of two gastrins extracted from hog antral mucosa. Gut, $5,103-117$.

Gregory, R. A., and Tracy, H. J. (1972). Isolation of two 'big gastrins' from Zollinger-Ellison tumour tissue. Lancet, 2, 797-799.

Rehfeld, J. F. (1972). Three components of gastrin in human serum. Gel filtration studies on the molecular size of immunoreactive serum gastrin. Biochem. biopsys. Acta (Amst.), 285, 364-372.

Rehfeld, J. F., and Stadil, F. (1973a). Gel filtration studies on immunoreactive gastrin in serum from Zollinger-Ellison patients. Gut, 14, 369-373.

Rehfeld, J. F., and Stadil, F. (1973b). Radioimmunoassay for gastrin employing immunosorbent. Scand. J. clin. Lab. Invest., 31, 459-464.

Rehfeld, J. F., and Stadil, F. (1973c). Effect of gastrin on basal- and glucose-stimulated insulin secretion in man. J. clin. Invest., 52, 1415-1426.

Rehfeld, J. F., Stadil, F., and Rubin, B. (1972). Production and evaluation of antibodies for the radioimmunoassay of gastrin. Scand. J. clin. Lab. Invest., 30, 221-232.

Stadil, F., and Rehfeld, J. F. (1972). Preparation of ${ }^{126}$ I-labelled synthetic human gastrin I for radioimmunoanalysis. Scand. J. clin. Lab. Invest., 30, 361-368.

Stadil, F., and Rehfeld, J. F. (1973). Determination of gastrin in serum: an evaluation of the reliability of a radioimmunoassay. Scand. J. Gastroent., 8, 101-112.

Yalow, R. S., and Berson, S. A. (1970). Size and charge distinctions between endogenous human plasma gastrin in peripheral blood and heptadecapeptide gastrins. Gastroenterology, 58, 609-615.

Yalow, R. S., and Berson, S. A. (1971). Further studies on the nature of immunoreactive gastrin in human plasma. Gastroenterology, 60, 203-214.

Yalow, R. S., and Berson, S. A. (1972). And now 'big, big' gastrin. Biochem. biophys. Res. Commun., 48, 391-395.

Yalow, R. S., and Wu, N. (1973). Additional studies on the nature of big big gastrin. Gastroenterology, 65, 19-27. 